\title{
Differential expression of glycoproteins containing $\alpha$-D-galactosyl groups on normal human breast epithelial cells and MCF-7 human breast carcinoma cells
}

\author{
J. Petryniak ${ }^{a}$, J. Varani ${ }^{b}$, P.R. Ervin ${ }^{c}$ and I.J. Goldstein ${ }^{a}$ \\ ${ }^{a}$ Department of Biological Chemistry, ${ }^{b}$ Department of Pathology and ${ }^{c}$ Department of Internal Medicine. University of \\ Michigan Medical School, Ann Arbor, Michigan (U.S.A.)
}

(Received 14 May 1991)

(Revision received 26 July 1991)

(Accepted 29 July 1991)

\section{Summary}

Cell surface glycoproteins were isolated from the lysates of ${ }^{125}$-labeled normal human mammary epithelial cells (NHMEC) and from the human breast carcinoma cell line MCF-7, of blood-group $O$ phenotype, by affinity chromatography on Griffonia simplicifolia I lectin. Sepharose. Specific elution of glycoproteins from the column with methyl $\alpha$-D-galactoside suggests the presence of $\alpha-D$-galactosyl groups on these moieties. SDS-PAGE analysis of isolated glycoproteins revealed both quantitative and qualitative differences between glycoproteins from normal and malignant cells. Three major glycoproteins of $M_{r} 180 \mathrm{kDa}, 85$ $\mathrm{kDa}$ and the $44 \mathrm{kDa}$ were obtained from

Correspondence to: Dr. Irwin J. Goldstein, Department of Biological Chemistry, University of Michigan Medical School, Room M4320, 1301 Catherine Road, Ann Arbor, MI 48109-0606, U.S.A.

Abbreviations: BSA, bovine serum albumin; FITC-fluorescein isothiocyanate; D-Gal, D-galactose; GS I, Griffonia simplicifolia I lectin; GS I-B, , Griffonia simplicifolia I- $\mathrm{B}_{4}$ isolectin; Me $\alpha \mathrm{DGal}$, methyl $\alpha$-D-galactoside; NHMEC, normal human mammary epithelial cells; PAGE, polyacrylamide gel electrophoresis; PBS, $0.01 \mathrm{M}$ phosphate buffer ( $\mathrm{pH} 7.1$ ) with $0.15 \mathrm{M} \mathrm{NaCl}$ and $0.02 \%$ azide (this buffer was free of divalent cations). $\mathrm{PBS} / \mathrm{Ca}^{2+}, \mathrm{PBS}$ containing $0.1 \mathrm{mM} \mathrm{CaCl}$; PMSF, phenylmethane sulfonyl fluoride: SDS, sodium dodecyl sulfate.
MCF-7 cells. The $180-k D a$ glycoprotein was absent in NHMEC and the 44-kDa glycoprotein was very weakly expressed in these cells. The only glycoprotein which was found in almost equal amount in the lysate from both normal and malignant cells was the $85-k D a$ glycoprotein. These results indicate differences between normal human mammary epithelial cells and one kind of malignant human mammary epithelial cells, in the expression of glycoproteins containing $\alpha$-D-galactosyl groups, irrespective of blood-group phenotype; they also demonstrate that $\alpha-D$ galactosyl group are expressed in a very restrictive manner on the surface of this tumor cell line.

Keywords: $\alpha$-D-galactose; breast; cancer

\section{Introduction}

The expression of specific oligosaccharide structures on tumor cells may contribute to their tumorigenicity or metastatic behavior [1]. Varani et al. [2] have shown that the expression of $\alpha$-D-galactosyl residues on the cell surface is strongly correlated with metastatic potential of murine fibrosarcoma cells. Highly 
metastatic cells from a number of different tumors expressed high levels of $\alpha$-D-galactosyl groups whereas low malignant cells from the same tumors did not. Moreover, results with the same cells indicated that these $\alpha$-Dgalactosyl groups were located on glycoproteins which may play a role in tumor cell attachment to collagen [3]. Castronovo et al. [4] reported the presence of $\alpha$-D-galactosyl groups on another highly malignant murine cell line, MO4. Their results also suggested that these groups may play a role in the formation of metastases, inasmuch as they were able to reduce lung colonization using anti- $\alpha$-Dgalactosyl antibodies. While previous studies have documented a strong, positive relationship between cell surface expression of $\alpha$-Dgalactosyl groups and malignant potential among murine tumor cell lines, much less work has been done in humans. Recently Castronovo et al. [5] also demonstrated the presence of $\alpha$-D-galactosyl groups on certain human tumor cell lines derived from human brain, breast and chorion as well as on some human breast cancer cells obtained at biopsy. These carbohydrate groups on choriocarcinoma cells (BEWO) were implicated in the process of attachment of these cells to laminin and to the vascular wall. While these previous studies support the notion that, in human as in mouse, the expression of $\alpha$-D-galactosyl groups is associated with the malignant phenotype, additional studies are necessary to determine the significance of such a relationship.

An important question to be addressed concerns the nature of the tumor cell surface molecules which bear the $\alpha$-D-galactosyl groups. Terminal $\alpha$-D-galactosyl groups are expressed on murine laminin from EHS sarcoma [6] and studies by McCoy et al. [7] indicated that laminin was responsible for at least some of the residues on murine fibrosarcoma cells. However, laminin probably accounts for only a minor portion of the $\alpha$-D-galactosyl groups on murine cells. Grimstad and Bosnes [8] indicated that $\alpha$-D-galactosyl groups which contribute to tumor cell attachment are located on molecules other than laminin. However, these molecules have not been identified. Further, laminin from human cells does not contain terminal $\alpha$-D-galactosyl groups [9].

In order to address these questions, we have developed a procedure for the isolation of glycoproteins bearing $\alpha$-D-galactosyl groups from the human cells. Our previous studies with glycoproteins containing $\alpha$-D-galactosyl groups on the surface of macrophages showed that the expression of these carbohydrates is limited to two major glycoproteins (Petryniak et al., unpublished data). Utilizing this procedure, we have compared the expression of glycoproteins bearing $\alpha$-D-galactosyl groups, on normal human breast epithelial cells and malignant MCF-7 human breast carcinoma cells. We found that there are few glycoproteins with $\alpha$-D-galactosyl groups on the surface of each kind of cell. Furthermore, there are substantial differences in the electrophoretic mobility profiles of the glycoproteins isolated from the normal and malignant cells.

\section{Materials and Methods}

\section{Cells}

Normal human mammary epithelial cells (NHMEC) and breast carcinoma cells. NHMEC were obtained from reduction mammoplasty of an individual with blood-group B phenotype and established in monolayer culture as described by Soule and McGrath [10]. Briefly, fresh tissue was dissected into small pieces with the aid of a scalpel and then dissociated in collagenase and hyaluronidase. Fibroblasts were removed by differential adhesion. The dissociated cells were then plated on plastic using a mixture of Dulbecco's modified minimal essential medium and Ham's F12 medium. The medium was prepared de novo without inclusion of $\mathrm{CaCl}_{2}$ in the balanced salt solution. The medium was supplemented with 100 units $/ \mathrm{ml}$ penicillin, $100 \mu \mathrm{g} / \mathrm{ml}$ streptomycin, cholera enterotoxin $(100 \mathrm{ng} / \mathrm{ml})$, epidermal growth factor $(20 \mathrm{ng} / \mathrm{ml})$, horse serum $(5 \%)$, insulin $(10 \mu \mathrm{g} / \mathrm{ml})$ and cortisol $\left(1.4 \times 10^{-6} \mathrm{M}\right)$. Finally, $\mathrm{CaCl}_{2}$ was added to 
bring the final concentration to $2 \mathrm{mM}$ for plating and cells were maintained in identical media with $16 \mu \mathrm{M} \mathrm{CaCl}_{2}$ after attachment.

MCF-7 human breast carcinoma cells were obtained from the American Type Culture Collection. This cell culture was established from an individual of blood group $\mathrm{O}$ phenotype. They were maintained in monolayer culture using minimal essential medium of Eagle with Earle's salts, non-essential amino acids, 100 units $/ \mathrm{ml}$ of penicillin, $100 \mu \mathrm{g} / \mathrm{ml}$ of streptomycin and $10 \%$ fetal bovine serum as culture medium. The cells were grown at $37^{\circ} \mathrm{C}$ and $5 \% \mathrm{CO}_{2}$ and subcultured by trypsinization as required.

\section{Reagents}

${ }^{14} \mathrm{C}$-Labeled molecular weight markerproteins were obtained from BRL Inc. (Bethesda, MD). These included: myosin, 200 $\mathrm{kDa}$; phosphorylase $\mathrm{B}, 97.4 \mathrm{kDa}$; bovine serum albumin, $68 \mathrm{kDa}$ and ovalbumin, 43 $\mathrm{kDa}$. Iodogen was from Pierce Rockford, IL. Griffonia simplicifolia I lectin was purified from seeds provided by Calbiochem as previously described [11]. The lectin was coupled to Sepharose $4 \mathrm{~B}$ by the $\mathrm{CNBr}$ procedure [12]. The conjugate contained approximately 1.1 $\mathrm{mg}$ of lectin per $\mathrm{ml}$ of settled beads.

\section{Cell surface labeling}

Both NHMEC and MCF-7 cells were surface-labeled with ${ }^{125}$ Iodine using the iodogen technique [13]. Briefly: to approximately $5 \times 10^{6}$ cells suspended in $2 \mathrm{ml}$ of PBS in a glass vial coated with $800 \mu \mathrm{g}$ of iodogen, $1.5 \mathrm{mCi}$ of ${ }^{125} \mathrm{Nal}$ (carrier free) was added. The suspension was mixed for $15 \mathrm{~min}$ at room temperature and cells were transferred to polypropylene tubes and washed four times with $15 \mathrm{ml}$ of PBS, sedimenting for $5 \mathrm{~min}$ at $400 \times g$ each time.

\section{Isolation of glycoproteins}

All purification steps were carried out at $4^{\circ} \mathrm{C}$, unless stated otherwise. ${ }^{125} \mathrm{I}$-Labeled cells were lysed and subjected to affinity chromatography. Lysis was carried out on an ice water-bath for $3 \mathrm{~min}(\mathrm{pH} 8.2)$ in $0.01 \mathrm{M}$ Tris $-\mathrm{HCl}$ buffer containing $0.15 \mathrm{M} \mathrm{NaCl}, 1 \%$ BSA and $4 \%$ Triton X-100. Freshly prepared protease inhibitors, were added to this lysing buffer just prior to lysis. Inhibitors included aprotinin $(10 \mu \mathrm{g})$, antipain $(50 \mu \mathrm{g})$, benzamidine $\mathrm{HCl}(100 \mu \mathrm{g})$, chymostatin $(100 \mu \mathrm{g})$, iodoacetamide $(1 \mathrm{mM})$ leupeptin $(10 \mu \mathrm{g})$, pepstatin $(100 \mu \mathrm{g}), 1,10$-phenanthroline (5 $\mathrm{mM})$ and PMSF ( $2 \mathrm{mM}$ ). (Numbers in parentheses represent final concentrations of inhibitor per $\mathrm{ml}$ of buffer). The lysate was centrifuged for $15 \mathrm{~min}$ in a microfuge at 15 $100 \times g$. The supernatant from the lysate was applied immediately to the Griffonia simplicifolia I lectin-Sepharose column $(0.7 \times$ $8 \mathrm{~cm})$. The column was equilibrated with $\mathrm{PBS} / \mathrm{Ca}^{2+}$ and washed successively with buffers (see Fig. 1) until the cpm dropped below 1000 per fraction. Absorbed material was specifically eluted with methyl $\alpha$-D-galactoside and analyzed by SDS-PAGE.

Acrylamide gel electrophoresis was carried out according to Laemmli [14] in $1.5 \mathrm{~mm}$ thick $7.5 \%$ acrylamide slab gels in the presence of $0.1 \%$ SDS, at constant current of $25 \mathrm{~mA}$. For autoradiography, gels were dried and exposed to Kodak X-Omat XAR 5 films for $7-14$ days. $M_{\mathrm{r}}$ of glycoproteins was determined from the standard curve fitted by linear regression.

\section{Results and Discussion}

In order to show that the structural difference between NHMEC and mammary carcinoma cells in the expression of the $\alpha$-D-Gal epitope is irrelevant to blood-group phenotype, MCF-7 carcinoma cells from a blood group $\mathrm{O}$ individual were chosen. These individuals do not express the $\alpha$-D-Gal epitopes inasmuch as they lack $\alpha$-Dgalactosyltransferase. In contrast, individuals with blood group B phenotype do contain $\alpha$ D-Gal residues linked to fucosylated oligosaccharides. Therefore NHMEC were from a blood group $\mathrm{B}$ individual to minimize the possible differences between these two kinds of cells regarding the expression of the $\alpha$-D-Gal 
epitope. Affinity chromatography of lysates from ${ }^{125}$ I-labeled NHMEC and from malignant MCF-7 cells on the Griffonia simplicifolia I lectin-Sepharose column resulted in peaks eluted specifically with methyl $\alpha$-D-galactoside (Fig. 1, Panel A and B). Incorporation of ${ }^{125}$ I into material eluted from the column indicates

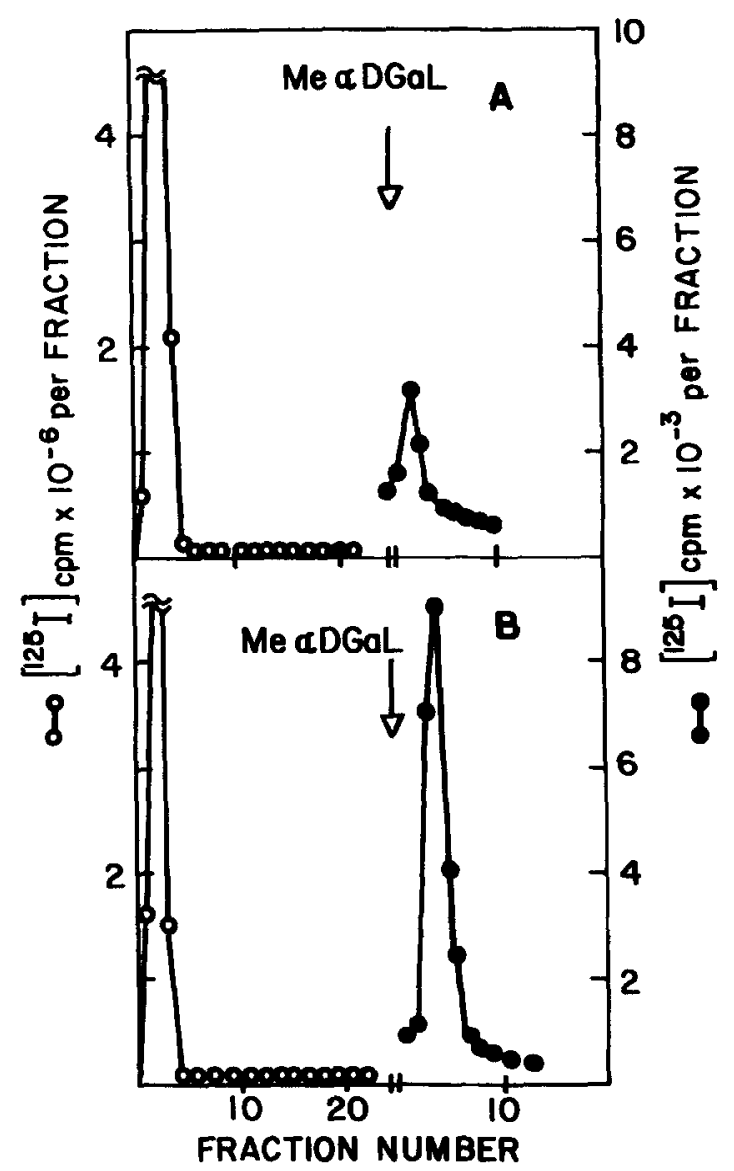

Fig. 1. Affinity chromatography on Griffonia simplicifolia I lectin-Sepharose of lysates from cells labeled with ${ }^{125} \mathrm{I}$. Lysates from NHMEC (panel A) and MCF-7 cells (panel B) were applied to a column $(0.7 \times$ $8.0 \mathrm{~cm}$ ) equilibrated in $\mathrm{PBS} / \mathrm{Ca}^{2+}$ and was washed successively with $50 \mathrm{ml}$ of $\mathrm{PBS} / \mathrm{Ca}^{2+}$ containing $1 \%$ Triton $\mathrm{X}-100$ and $50 \mathrm{ml}$ of PBS/ $\mathrm{Ca}^{2+}$ without Triton X-100. The column was equilibrated with $\mathrm{PBS} / \mathrm{Ca}^{2+}$ containing $0.2 \%$ octyl glucoside (buffer A). Fraction of $1.3 \mathrm{ml}$ were collected. The flow rate was $16 \mathrm{ml} / \mathrm{h}$. Absorbed material was eluted with $15 \mathrm{ml}$ of $100 \mathrm{mM}$ methyl $\alpha$-Dgalactoside in buffer $A$. that the eluted material is probably a glycoprotein in nature and that it contains terminal $\alpha$-Dgalactosyl groups. There was more ${ }^{125}$ Ilabeled material eluted from the lysate of MCF-7 cells than NHMEC. However, an answer to the question as to whether this difference results from a different number of receptors on each kind of cell would require quantitative studies. Materials in both peaks eluted from Griffonia simplicifolia I lectinSepharose column were analyzed by SDSPAGE (Fig. 2). Autoradiograms of the material resolved in the gel revealed both qualitative and quantitative difference between glycoproteins from normal and malignant cells. Several
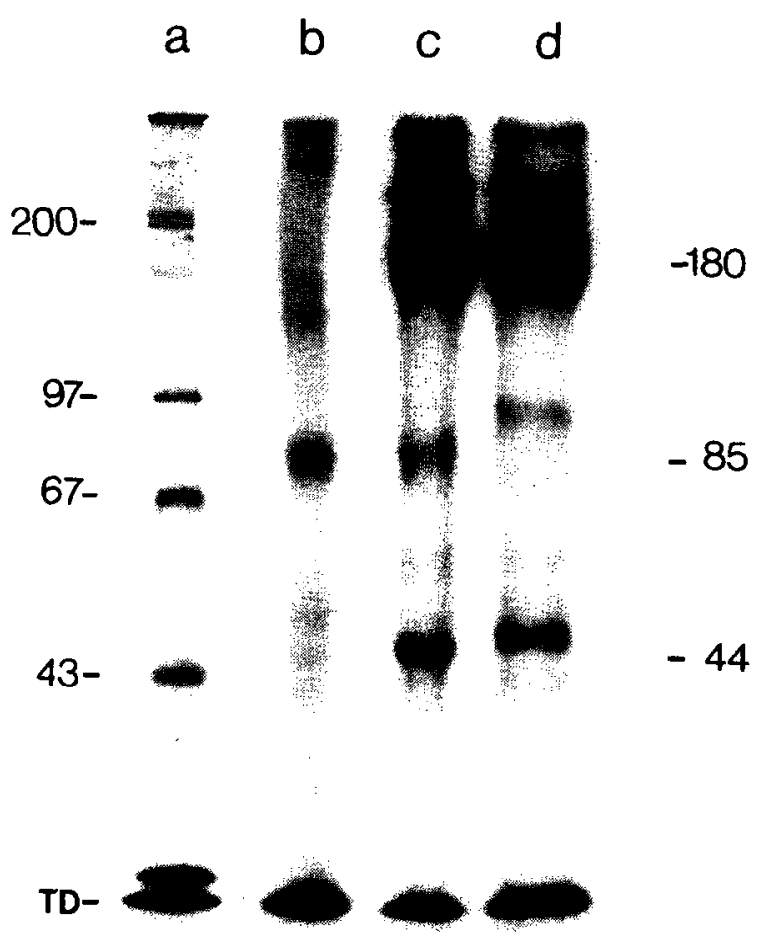

Flg. 2. Autoradiogram of SDS-PAGE of ${ }^{125}$ l-labeled glycoproteins from NHMEC and MCF-7 cells. Glycoproteins were isolated by affinity chromatography on Griffonia simplicifolia I lectin-Sepharose and eluted with methyl $\alpha$-D-galactoside. Electrophoresis was carried out in a $7.5 \%$ acrylamide gel at constant current of $25 \mathrm{~mA}$. (a) molecular weight markers; (b) NHMEC; (c) MCF-7 cells (unreduced conditions); (d) MCF-7 cells (reduced with $2 \%$ DTT). 
glycoproteins are expressed specifically or at higher levels in the MCF-7 cells.

Three major glycoproteins of $M_{\mathrm{r}} 180 \mathrm{kDa}$, $85 \mathrm{kDa}$ and $44 \mathrm{kDa}$ were found in the lysate from MCF-7 cells (Fig. 2c). These glycoproteins appear to be cell membrane components inasmuch as they were labeled on the surface of intact cells with ${ }^{125} 1$ by the insoluble iodogen reagent which can not enter the cell. Of these three glycoproteins in the tumor cell lysate, the glycoprotein of $180 \mathrm{kDa}$ represents the strongest band; it was completely absent in the lysate from normal cells (Fig. 2b). This glycoprotein was also insensitive to reduction with $\beta$-mercaptoethanol (Fig. 2d) suggesting the lack of subunit structure linked by disulfide bonds. It will be of interest to determine if this glycoprotein is breast cancer-specific or whether it is may be present in other types of cancer cells. The 44-kDa glycoprotein, which also gave a strong band in the lysate from MCF-7 cells, was barely detectable in the lysate from NHMEC (Fig. 2b). The 44-kDa glycoprotein from MCF-7 cells migrated as a sharp band whereas that from normal cells moved as a broader, diffuse band (Fig. $2 b, c$ ). Whether these glycoproteins from the two types of cells are the same remains to be determined? The only glycoprotein which appeared to be present in approximately equal amounts in the lysate from both kinds of cells was the $85-\mathrm{kDa}$ component. Again, whether they are identical cannot be answered at this point.

These results suggest that during the process of malignant transformation of MCF-7 cells, glycoproteins containing $\alpha$-D-galactosyl groups are altered and/or expressed and suggest that the $\alpha$-D-Gal epitope on the MCF-7 carcinoma cells is different from the blood-group-B structure. Determination of the linkage between the $\alpha$-D-Gal groups and the subterminal carbohydrate would be of obvious interest. Immunochemical studies suggest that this linkage might be $\alpha 1-3$, but such an epitope has not been found in humans [15]. Its appearance in MCF-7 breast cancer cells might be of general biological significance and the glycoproteins described here might provide a tool for such structural studies. In addition to this major component, lysates from normal cells showed additional, very weak bands of $40 \mathrm{kDa}, 50$ $\mathrm{kDa}$ and a diffuse zone in the range of $133-167 \mathrm{kDa}$. These were absent from lysates of the MCF-7 cells (Fig. 2c). Both the $85-\mathrm{kDa}$ and $44-\mathrm{kDa}$ glycoproteins from MCF-7 cells showed a decrease in their mobility after reduction with $\beta$-mercaptoethanol and their apparent $M_{\mathrm{r}}$ increased to $100 \mathrm{kDa}$ and $48 \mathrm{kDa}$, respectively. This suggests that they may consist of single polypeptide chains with intramolecular disulfide bonds. The $180-\mathrm{kDa}$, 85-kDa and 44-kDa glycoproteins we isolated from MCF-7 cells are clearly different from laminin. This is in agreement with the observation of Grimstad and Bosnes who stated the $\alpha$ D-galactopyranosyl end-groups occur on species of cell-surface molecules other than laminin [8].

Are the glycoproteins isolated from MCF-7 cells identical to those previously described? Carcinoembryonic antigen (CEA) is also in the range of $M_{\mathrm{r}} 180 \mathrm{kDa}$ [16] and has been found on breast carcinoma cells [17]. However CEA as reported by Lisowska et al. [18] has a subunit structure and, moreover, does not contain $\alpha$-D-galactosyl groups [19]. In only very few cases have specific glycoproteins been shown to be associated with breast carcinoma cells [20-25]. These include a $180 \mathrm{kDa}$ glycoprotein defined by monoclonal antibodies as described by Ring et al. [25]; however, there are differences between the $180 \mathrm{kDa}$ glycoprotein described here, and the one described previously with the same molecular weight. The apparent $M_{\mathrm{r}}$ of the glycoprotein described by Ring et al. increased to $200 \mathrm{kDa}$ after reduction with $\beta$-mercaptoethanol whereas the glycoprotein we isolated was insensitive to reduction. Moreover, these investigators did not detect this glycoprotein on MCF-7 cells. A membrane glycoprotein associated with human breast cancer tissue described by Edwards et al. [21] has a $M_{\mathrm{r}}$ of $43 \mathrm{kDa}$. Whether this glycoprotein is identical to the glycoprotein of $M_{\mathrm{T}} 44 \mathrm{kDa}$ we isolated, remains to be determined. All other glycoproteins described 
previously [19,21-23] have differed in molecular weight from the glycoproteins described here.

Currently, the biological role(s) of breast cancer-associated glycoproteins remains unknown. However, involvement of molecules containing $\alpha$-D-galactosyl groups in the formation of metastases has been indicated. $\alpha$-DGalactosyl groups are more strongly expressed on murine tumor cells than on those from humans $[26,27]$. Nevertheless, their presence on tumor cells from both species pose the question as to whether there may be an evolutionary relationship between these glycoproteins, and whether they might play a role in human tumor metastasis. Identification of molecules containing this carbohydrate group on tumor cell surfaces, as well as their full biochemical and immunochemical characterization, may provide an approach to address these questions.

\section{Acknowledgement}

This research was supported by National Institutes of Health Grant CA 20424.

\section{References}

1 Rademacher, T.W., Parekh, R.B. and Dwek, R.A. (1988) Glycobiology. Ann. Rev. Biochem., 57, 785-838.

2 Varani, J., Lovett, E.J., Wicha, M., Malinoff, H. and McCoy, J.P., Jr. (1983) Cell surface $\alpha$-D-galactopyranosyl end groups: use as markers in the isolation of murme tumor cell lines with different cancer-causing potential. J. Natl. Cancer Inst., 71, 1281-1287

3 Grimstad, I.A., Varani, J. and McCoy, J.P. Jr. (1984) Contribution of $\alpha$-D-galactopyranosyl end groups to attachment of highly and low metastatic murine fibrosarcoma cells to various substrates. Exp. Cell. Res., 155, $345-348$.

4 Castronovo, V. Foidart, J.M., Li Vecchi, M., Foidart, d.B., Bracke, M., Mareel, M. and Mahieu, P. (1987) Human anti-alpha-galactosyl IgG reduces the lung colonization by murine MO4 cells. Invas. Metastas., 7, $325-345$.

5 Castronovo, V., Colin, C., Parent, B., Foidart, J-M., Lambotte, R. and Mahieu, P. (1989) Possible Role of human natural anti-gal antibodies in the natural antitumor defense system. J. Natl. Cancer Inst., 81, 212-216

6 Shibata, S., Peters, B.P., Roberts, D.D., Goldstein, I.J. and Liotta, L.A. (1982) Isolation of laminin by affinity chromatography on immobilized Griffonia simplicifolia I lectin. FEBS Lett., 142, 194-198.

7 McCoy, J.P. Jr., Goldstein, I.J. and Varani, J. (1985) A review of studies in our laboratory regarding ELLA methodology for the study of cell surface carbohydrates from tumors of varying metastatic potential. Tumor Biol. $6,99-114$

8 Grimstad, l.A and Bosnes, V. (1987) Cell surface lamininlike molecules and $\alpha$-D-galactopyranosyl end groups of cloned strongly and weakly metastatic murine fibrosarcoma cells. Int. J. Cancer, 40, 505-510

9 Klein, R., Timpl, R., Zanetti, F.R., Plester, D. and Berg, P.A. (1989) High antibody levels against mouse laminin with specificity for galactosyl-(alpha $1-3$ ) galactose in patients with inner ear diseases. Ann. Otol. Rhinol. Laryngol., 98, 537-542.

10 Soule, H.D. and McGrath, C.M. (1986) A simplified method for passage and long-term growth of human mammary epithelial cells. In vitro Cell. Dev. Biol., 22, 6- 12

11 Delmotte, F.M. and Goldstein, I.J. (1980) Improved procedure for purification of the Bandeiraea simplicifolia I isolectins and Bandeiraea simplicifolia II lectin by affinity chromatography. Eur. J. Biochem., 12, 219-223.

12 Cuatrecasas, P. (1970) Protein purification by affinity chro matography. J. Biol. Chem., 245, $3059-3065$

13 Markwell, M.A. and Fox, F.C. (1978) Surface-specific iodination of membrane proteins of viruses and eucaryotic cells using 1,3,4,6-tetrachloro-3,6-diphenylglycoluril. Biochemistry. 17, 4807-4817

14 Laemmli, U.K. (1970) Cleavage of structural proteins dur ing the assembly of the head of bacteriophage T4. Nature, $227,680-685$

15 Galili U., Shohet, S.B., Kobrin, E., Stults, C.L.M. and Mocher, B.A. (1988) Man, Apes and Old World Monkeys differ trom other mammals in the expression of $\alpha$-D-Gal epitopes on nucleated cells. J. Biol. Chem., 263 , $17755-17762$

16 Luknar-Gabor, N., Fenger, U., Wagener, C. and Breuer, $H$. (1982) Characterization of variant of carcinoembryonic antigen (CEA) using monoclonal and polyclonal anti-CEA antibodies. Biochem. Biophys. Res. Commun., 109, $1270-1275$.

17 Hollinshead, A.C. (1987) Biological markers of breast can cer: a review. Cancer Invest., 5, 581-591.

18 Lisowska, E., Krop-Watorek, A. and Sedlaczek, P. (1983) The dimeric structure of carcinoembryonic antigen (CEA) Biochem. Biohys. Res. Commun., 115, 206-211.

19 Hammarstrom, S., Enguall, E., Johansson, B.G. Svensson, S., Sundblad, G. and Goldstein, I.J. (1975) Nature of the tumor-associated determinant(s) of carcinoembryonic antigen. Proc. Natl. Acad. Sci. U.S.A., 72, $1528-1532$.

20 Jacobelli, S., Arno, E., D'Orazio, A. and Coletti, G. (1986) Detection of antigens recognized by novel monoclonal an tibody in tissue and serum from patients with breast cancer. Cancer Res., 46, 3005-3010.

21 Edwards, D.P., Grzyb, K.T., Dressler, L.G., Mansel, R.E., 
Zava, D.T., Sledge, G.W. and McGuire, W.L. (1986) Membrane glycoprotein associated with human breast cancer. Cancer Res., 46, 1306-1317.

22 Johnson, V.G., Schlom, J., Paterson, A.J., Bennett, J., Maganani, J.L. and Colcher, D. (1986) Analysis of human tumor-associated glycoprotein (TAG-72) identified by monoclonal antibody B72.3. Cancer Res., 46, 850-857.

23 Burchell, J., Gendler, S., Taylor-Papadimitriou, J., Girling, A., Lewis, A., Mills, R. and Lamport. D. (1987) Development and characterization of breast cancer reactive monoclonal antibodies directed to the core protein of the human milk mucin. Cancer Res., 47, 5476-5482.

24 Keydar, I., Chou, C.S., Hareuveni, M., Tsarfaty, I., Sahar, E., Selzer, G., Chaitchik, S, and Hizi, A. (1989) Production and characterization of monoclonal antibodies identifying breast tumor-associated antigens. Proc. Natl. Acad. Sci. U.S.A., 86, 1362-1366.

25 Ring, D.B., Kassel, J.A., Hsieh-Ma S.T., Bjorn, M.J., Tringale, F. Eaton, A.M., Reid, S.A., Frankel, A.E. and Nadji, M. (1989) Distribution and physical properties of BCA200, a $M_{\mathrm{r}} 200,000$ glycoprotein selectively associated with human breast cancer. Cancer Res., 49, 3070-3080.

26 Peters, B. and Goldstein, I.J. (1979) The use of fluorescein-conjugated Bandeiraea simplicifolia $\mathrm{B}_{4}$ isolectin as a histochemical reagent for the detection of $\alpha-D$ galactopyranosyl groups. Exp. Cell Res., 120, $321-324$.

27 Eckhardt, A.E. and Goldstein, I.J. (1983) Occurence of $\alpha$ D-galactosyl-containing glycoproteins on Ehrlich tumor cell membranes. Biochemistry 22, 5280-5289. 